\title{
MONOPOLY AND COMPETITION ON BULGARIAN PENSION MARKET
}

\author{
P. Enev* \\ Industrial Business and Entrepreneurship Department, Trakia University, Stara Zagora, Bulgaria
}

\begin{abstract}
Challenges facing social security system in Bulgaria occurred as a result of radical political and economic changes after 1989 call for a reform and a new philosophy in the social security system. Multi-pillar pension system was introduced and the operation of private pension insurance companies was launched. Amid deepening demographic crisis and worsening economic climate the future role of supplementary pension insurance is essential for the achievement of expected results of the pension reform.

The article's main goal is to study how pension insurance companies in Bulgaria operate in the free market environment.

To achieve this goal the following tasks are completed:

- Analyzed are the market concentration and market shares of the pension insurance companies and the net assets managed by them from mandatory and voluntary funds;

- Analyzed are some of the existing problems and measures are proposed to overcome them.

The methods utilized during the study are the system approach, statistical evaluations, analysis and synthesis, comparison methods and others.
\end{abstract}

Key words: pension insurance companies, pension funds, trends

\section{INTRODUCTION}

Reforms in the pension system are necessary due to accumulated deformation in this area for many years and extremely unfavorable demographic situation as well.

The goal of the pension reform in Bulgaria is building a model of a modern pension system where supplementary pension insurance mandatory and voluntary, is designed to supplement pension income received by the state pension system. The realization of this goal is possible by complementing state pension with additional pension received by pension funds for additional mandatory and voluntary supplementary pension insurance managed by licensed pension insurance companies. The system of supplementary pension insurance functions funded by the idea that the funds from contributions and to invest together with income from investing accumulated in individual pension accounts of individuals. The ultimate goal of the reform provides income-replacement ratio ${ }^{1}$ of the three pillars to be $70-80$ percent, including:

\footnotetext{
*Correspondence to: Plamen Enev, Industrial Business and Entrepreneurship Department, Trakia University, Stara Zagora, Bulgaria, tel. 042699 418,enev74@abv.bg
}

first pillar - 40-45 percent; second pillar - 15-20 percent; third pillar - 10-20 percent;

\section{DISCUSION AND RESULTS}

Demographic crisis and poor economic conditions have a negative impact on financial stability and efficiency of the public pension system, which highlights the future role of supplementary pensions. In this case it is necessary to analyze trends in the market by presenting and analyzing the results of its major participants - companies and pension funds managed by them.

Pension insurance companies (PICs) have different market shares in terms of the number of insured persons, the amount of net assets in funds managed by them, the amount of equity and other indicators. In this differentiation naturally the question arises - what competitive environment companies operate in Bulgaria? To answer this question must be analyzed market shares of the insured and the net assets of PICs and analyze the values of the

\footnotetext{
${ }^{1}$ Income-replacement ratio - the ratio between the average pension and the average social security insurance income
} 
Herfindahl - Hirschman Index ${ }^{2}$.

When a company or companies have high market shares, the risk of monopolization is large and competition loses its importance. Conversely, the lower the market concentration, the more competitive the insurance market.

Market share of pension insurance companies by the number of insured persons in the funds managed by them.

Table 1. Market concentration of insured persons in pension insurance companies

\begin{tabular}{|l|r|r|r|}
\hline & \multicolumn{3}{|l|}{ lICs`market share (\%) } \\
on the number of insured \\
Pension Insurance Companies & \multicolumn{1}{l|}{} \\
& \multicolumn{1}{|l}{} \\
\hline & 2012 & 2013 & 2014 \\
\hline PIC "DOVERIE" PLC & 30.64 & 29.35 & 27.76 \\
\hline PIC "ALLIANZ BULGARIA" PLC & 22.16 & 22.2 & 22.59 \\
\hline PIC "SAGLASIE" PLC & 12.33 & 12.25 & 11.95 \\
\hline PIC "DSK-RODINA" PLC & 11.28 & 11.7 & 12.28 \\
\hline PI"CCB-SILA"PLC & 9.34 & 9.46 & 9.7 \\
\hline "ING PIC" PLC & 8.2 & 8.4 & 8.56 \\
\hline "PIC-FUTURE" PLC & 3.2 & 3.46 & 3.73 \\
\hline PIC "TOPLINA" PLC & 1.97 & 2.02 & 2.02 \\
\hline "PENSIONNOOSIGURITELEN INSTITUT" PLC & 0.88 & 1.16 & 1.41 \\
\hline Herfindahl-Hirschman Index & $\mathbf{1 8 7 8}$ & $\mathbf{1 8 1 9}$ & $\mathbf{1 7 6 2}$ \\
\hline
\end{tabular}

Source: Financial Supervision Commission and own calculations

The data in Table 1 shows that the highest market shares of all insured persons in the funds for mandatory and voluntary pension insurance have companies appeared first on the insurance market in its new generation in the mid-90s. Some of them even "devoured" smaller pension companies. Other PICs as PI"CCB-SILA"PLC for example, achieved relatively decent market share through mergers of smaller companies in them. Emerging companies as PIC "TOPLINA" PLC and "PENSIONNOOSIGURITELEN INSTITUT" PLC have a very modest share of insured persons in them. Data show that the value of the Herfindahl - Hirschman Index is above 1800 , which means that we have a high market concentration in the distribution of insured persons by PICs in Bulgaria in 2012 and 2013. This concentration is mainly due to the marketing strategy of those PICs, which first began operations in Bulgaria and accumulate an enviable confidence. Secondly, some of these companies have good relations with trade unions and employers' organizations, and they assist in choosing a fund of mandatory and voluntary pension insurance.

Market concentration net assets of companies

Table 2. Market concentration by net assets

\begin{tabular}{|l|r|r|r|}
\hline \multirow{2}{*}{ Pension Insurance Companies } & \multicolumn{3}{|l|}{ PIC`ssmarket share (\%) } \\
& by net assets & \\
\hline & 2012 & \multicolumn{1}{|c|}{2013} & \multicolumn{1}{c|}{2014} \\
\hline PIC "DOVERIE" PLC & 31.61 & 29.51 & 27.47 \\
\hline PIC "ALLIANZ BULGARIA" PLC & 23.17 & 23.07 & 23.26 \\
\hline PIC "SAGLASIE" PLC & 12.03 & 12.14 & 11.98 \\
\hline PIC "DSK-RODINA" PLC & 10.46 & 11.55 & 12.67 \\
\hline PI"CCB-SILA"PLC & 9.5 & 9.69 & 9.95 \\
\hline "ING PIC" PLC & 9.65 & 10.11 & 10.43 \\
\hline "PIC-FUTURE" PLC & 1.75 & 1.87 & 1.93 \\
\hline PIC "TOPLINA" PLC & 1.44 & 1.47 & 1.45 \\
\hline "PENSIONNOOSIGURITELEN INSTITUT" PLC & 0.39 & 0.59 & 0.86 \\
\hline Herfindahl-Hirschman Index & $\mathbf{1 9 7 9}$ & $\mathbf{1 8 8 6}$ & $\mathbf{1 8 1 5}$ \\
\hline
\end{tabular}

Source: Financial Supervision Commission and own calculations

${ }^{2}$ Financial Supervision Commission in Bulgaria recommended differentiation of these three intervals of values Herfindahl - Hirschman Index, namely: below 1000 - a highly competitive market; between 1000 and 1800 - a market with moderate competitive environment and concentration; above 1800 - less competitive market; 
Data for 2012, 2013 and 2014 confirmed the same logic of market concentration achieved net pension assets, as well as insured persons oldest companies occupy high market share of the total amount of accumulated pension assets. The majority of companies have achieved stable market shares about over 10 percent thanks to the constant marketing policy, while others - through mergers of other companies in them.

The value of the Herfindahl - Hirschman Index is above 1800 , which means that once again we have a high market concentration in the distribution of the managed companies net pension assets. Market concentration by net assets is greater than the distribution by insured in PICs` funds. This shows that the Bulgarian pension insurance market is highly concentrated, which could prove an obstacle to free competition. In particularly unfavorable position are newly registered companies.

Market shares and market concentration by type of pension funds.

Table 3. Market concentration by insured persons in UPF.

\begin{tabular}{|l|r|r|r|}
\hline \multirow{2}{*}{ Universal Pension Fund } & \multicolumn{3}{|c|}{$\begin{array}{l}\text { UPFs`market share (\%) by the } \\
\text { number of insured persons }\end{array}$} \\
\hline & \multicolumn{1}{c|}{2012} & \multicolumn{1}{c|}{2013} & \multicolumn{1}{c|}{2014} \\
\hline UPF "DOVERIE" & 31,53 & 30,5 & 28,34 \\
\hline ZUPF "ALLIANZ BULGARIA" & 20,01 & 20,23 & 20,76 \\
\hline UPF "SAGLASIE" & 12,85 & 12,67 & 12,29 \\
\hline UPF "DSK - RODINA" & 11,44 & 11,79 & 12,34 \\
\hline UPF "CCB - SILA" & 9,22 & 9,4 & 9,7 \\
\hline "ING UPF" & 8,62 & 8,83 & 8,97 \\
\hline "UPF - FUTURE" & 3,68 & 4 & 4,31 \\
\hline UPF "TOPLINA" & 1,66 & 1,72 & 1,72 \\
\hline $\begin{array}{l}\text { UPF "PENSIONNOOSIGURITELEN } \\
\text { INSTITUT" }\end{array}$ & 0,99 & 1,31 & 1,57 \\
\hline Herfindahl-Hirschman Index & $\mathbf{1 8 5 8}$ & $\mathbf{1 7 9 9}$ & $\mathbf{1 7 3 5}$ \\
\hline
\end{tabular}

Source: Financial Supervision Commission and own calculations

Data show that the highest market shares have the "old" PICs` universal funds, which is explained by the above factors. The value of the Herfindahl - Hirschman is above 1800 for 2012, which means that we have a high market concentration in the distribution of the insured in universal pension funds in Bulgaria, while in the next 2 years there has been a slight decline in this index.

Table 4. Market concentration by UPFs`net assets

\begin{tabular}{|l|r|r|r|}
\hline \multirow{2}{*}{ Universal Pension Fund } & \multicolumn{3}{l}{ UPFs' market share (\%) by net } \\
& \multicolumn{1}{l}{ assets } & \multicolumn{1}{c|}{} \\
\hline & 2012 & \multicolumn{1}{c|}{2013} & \multicolumn{1}{c|}{2014} \\
\hline UPF "DOVERIE" & 33,38 & 31,05 & 28,87 \\
\hline ZUPF "ALLIANZ BULGARIA" & 20,91 & 21,15 & 21,46 \\
\hline UPF "SAGLASIE" & 12,09 & 11,93 & 11,68 \\
\hline UPF "DSK - RODINA" & 11,01 & 12,17 & 13,31 \\
\hline UPF "CCB - SILA" & 9,36 & 9,6 & 9,95 \\
\hline "ING UPF" & 9,82 & 10,28 & 10,56 \\
\hline "UPF - FUTURE" & 1,97 & 2,1 & 2,19 \\
\hline UPF "TOPLINA" & 1,02 & 1,07 & 1,08 \\
\hline UPF "PENSIONNOOSIGURITELEN & 0,44 & 0,65 & 0,9 \\
INSTITUT" & $\mathbf{2 0 0 8}$ & $\mathbf{1 9 0 6}$ & $\mathbf{1 8 2 5}$ \\
\hline Herfindahl-Hirschman Index & &
\end{tabular}

Source: Financial Supervision Commission and own calculations

The data in Table 4 show almost the same distribution of market shares in terms of the universal pension funds, as well as the insured. The general conclusion can be made to the universal pension funds is that has highly concentrated market and this concentration is more pronounced in net pension assets.

Market shares and market concentration of insured persons in Profesional Pension Funds. 
Table 5. Market concentration by insured persons in PPF

\begin{tabular}{|l|r|r|r|}
\hline & \multicolumn{4}{|l|}{$\begin{array}{l}\text { PPFs`market share (\%) by } \\
\text { number of fund members }\end{array}$} \\
\hline & \multicolumn{1}{|c|}{2012} & \multicolumn{1}{|c|}{2013} & \multicolumn{1}{c|}{2014} \\
\hline PPF "DOVERIE" & 29,52 & 27,95 & 25,89 \\
\hline ZPPF "ALLIANZ BULGARIA" & 15,8 & 16,05 & 16,25 \\
\hline PPF "SAGLASIE" & 14,87 & 15 & 15,02 \\
\hline PPF "DSK - RODINA" & 10,06 & 10,5 & 11,22 \\
\hline PPF "CCB - SILA" & 11,68 & 11,68 & 11,62 \\
\hline "ING PPF" & 8,11 & 8,28 & 8,6 \\
\hline "PPF - FUTURE" & 2,64 & 2,73 & 2,98 \\
\hline PPF "TOPLINA" & 5,87 & 6,01 & 6,07 \\
\hline $\begin{array}{l}\text { PPF "PENSIONNOOSIGURITELEN } \\
\text { INSTITUT" }\end{array}$ & 1,45 & 1,8 & 2,35 \\
\hline Herfindahl-Hirschman Index & $\mathbf{1 6 8 9}$ & $\mathbf{1 6 2 6}$ & $\mathbf{1 5 4 6}$ \\
\hline
\end{tabular}

Source: Financial Supervision Commission and own calculations

The value of the Herfindahl - Hirschman Index is below 1800, which means that profesional pension funds do not have a high degree of concentration, but it is moderate on this indicator.

Table 6. Market concentration by PPFs`net assets

\begin{tabular}{|l|r|r|r|}
\hline \multirow{2}{*}{ Profesional Pension Fund } & \multicolumn{4}{l}{$\begin{array}{l}\text { PPFs`market share (\%) by net } \\
\text { assets }\end{array}$} \\
\hline & 2012 & 2013 & \multicolumn{1}{l|}{2014} \\
\hline PPF "DOVERIE" & 31,8 & 28,8 & 26,07 \\
\hline ZPPF "ALLIANZ BULGARIA" & 17,62 & 17,77 & 17,91 \\
\hline PPF "SAGLASIE" & 16,6 & 17,8 & 18,25 \\
\hline PPF "DSK - RODINA" & 9,85 & 10,73 & 11,86 \\
\hline PPF "CCB - SILA" & 11,45 & 11,4 & 11,42 \\
\hline "ING PPF" & 6,06 & 6,48 & 7,04 \\
\hline "PPF - FUTURE" & 1,21 & 1,27 & 1,21 \\
\hline PPF "TOPLINA" & 5 & 5,09 & 4,97 \\
\hline PPF "PENSIONNOOSIGURITELEN & 0,41 & 0,66 & 1,27 \\
INSTITUT" & $\mathbf{1 8 8 9}$ & $\mathbf{1 7 7 7}$ & $\mathbf{1 6 8 2}$ \\
\hline Herfindahl-Hirschman Index & & & \\
\hline
\end{tabular}

Source: Financial Supervision Commission and own calculations

The value of the Herfindahl-Hirschman index is above 1800 for 2012, which means there is a high market concentration in the distribution by net pension assets in profesionall pension funds in Bulgaria. This concentration is much higher than the concentration of insured persons in the profesional pension funds. This is mostly due to the selective marketing policy of some of the PICs that are attracted to members of their managed UPF almost all workers from companies with very high gross wages. In 2013 and 2014 there are a tendency towards lower market concentration, because the index is below 1800 .

Market shares and market concentration by insured persons in Voluntary Pension Funds. 
Table 7. Market concentration by number of fund members in VPF

\begin{tabular}{|l|r|r|r|}
\hline Voluntary Pension Fund & \multicolumn{3}{|l}{$\begin{array}{l}\text { VPFs market share } \\
\text { number of fund members }\end{array}$} \\
\hline & 2012 & \multicolumn{1}{c|}{ by } \\
\hline VPF "DOVERIE" & 26,63 & 26,28 & 25,56 \\
\hline VPF "ALLIANZ BULGARIA" & 37 & 36,28 & 36,32 \\
\hline VPF "SAGLASIE" & 8,48 & 8,81 & 8,76 \\
\hline VPF "DSK - RODINA" & 10,02 & 10,78 & 11,49 \\
\hline VPF "CCB - SILA" & 9,06 & 8,93 & 8,89 \\
\hline "ING VPF" & 6,02 & 6,16 & 6,28 \\
\hline "VPF - FUTURE" & 0,81 & 0,78 & 0,75 \\
\hline VPF "TOPLINA" & 1,96 & 1,94 & 1,89 \\
\hline $\begin{array}{l}\text { VPF "PENSIONNOOSIGURITELEN } \\
\text { INSTITUT" }\end{array}$ & 0,02 & 0,04 & 0,06 \\
\hline Herfindahl-Hirschman Index & $\mathbf{2 3 7 3}$ & $\mathbf{2 3 2 3}$ & $\mathbf{2 3 0 4}$ \\
\hline
\end{tabular}

Source: Financial Supervision Commission and own calculations

Data show that the distribution of the insured in the voluntary pension funds the largest share belongs to the voluntary fund of the PIC "Allianz - Bulgaria". This fact is probably due to the fact that the group "Alliance" actively marketing policy is not only in the area of pensions but also in insurance. The value of the Herfindahl - Hirschman Index is highest, which means the voluntary pension funds have the highest degree of concentration on this indicator.

Table 8. Market concentration by VPFs`net assets

\begin{tabular}{|l|r|r|r|}
\hline \multirow{2}{*}{ Voluntary Pension Fund } & \multicolumn{3}{l}{ VPFs`market share (\%) by net } \\
& assets & \multicolumn{1}{l|}{} \\
\hline & 2012 & 2013 & \multicolumn{1}{l|}{2014} \\
\hline VPF "DOVERIE" & 18,8 & 17,94 & 16,93 \\
\hline VPF "ALLIANZ BULGARIA" & 44,85 & 44,09 & 44,68 \\
\hline VPF "SAGLASIE" & 7,56 & 8,49 & 8,47 \\
\hline VPF "DSK - RODINA" & 6,22 & 6,39 & 6,88 \\
\hline VPF "CCB - SILA" & 8,82 & 8,87 & 8,58 \\
\hline "ING VPF" & 11,79 & 12,36 & 12,82 \\
\hline "VPF - FUTURE" & 0,68 & 0,59 & 0,4 \\
\hline VPF "TOPLINA" & 1,26 & 1,23 & 1,15 \\
\hline VPF "PENSIONNOOSIGURITELEN & 0,02 & 0,04 & 0,09 \\
INSTITUT" & $\mathbf{2 6 8 0}$ & $\mathbf{2 6 1 2}$ & $\mathbf{2 6 4 1}$ \\
\hline Herfindahl-Hirschman Index & & &
\end{tabular}

Source: Financial Supervision Commission and own calculations

The value of the Herfindahl - Hirschman Index is above 2000 , which means there is extremely high market concentration in the distribution of net pension assets by voluntary pension funds in Bulgaria. This concentration is much higher than the concentration of insured persons in the same pension funds.

\section{CONCLUSIONS}

High market concentration and the presence of very large and very small companies do not cause any serious threats to the financial stability of PICs and funded pension system as a whole. This conclusion is corect, however, only the phase of accumulation of pension assets due to the fact that pension schemes in Bulgaria are defined-contribution schemes.
Naturally, large companies benefit from economies of scale and therefore their financial indicators are better. High market concentration and polarization of PICs in market shares can be a serious problem for small companies to phase payment. For these reasons, the process of consolidation of PICs in Bulgaria will continue, but not administrative and purely economic reasons.

\section{REFERENCES}

1. Hristoskov J,Social security reforms,Sofia.,(2010)

2. Codex of Social Security Insurance (2003)

3. ILO, Financing social protection (2004)

4. http://www.fsc.bg/ 